\title{
Metschnikowia cubensis sp. nov., a yeast species isolated from flowers in Cuba
}

\author{
Abel Fidalgo-Jiménez, ${ }^{1,2}$ Heide-Marie Daniel, ${ }^{2}$ Pierre Evrard, ${ }^{2}$ \\ Cony Decock ${ }^{2}$ and Marc-André Lachance ${ }^{3}$
}

Correspondence

Heide-Marie Daniel

heide-marie.daniel@uclouvain.be

\author{
${ }^{1}$ Instituto de Ecología y Sistemática (IES), Carretera de Varona, km 31/2 Capdevila, Boyeros, AP \\ 8029, CP 10800, Ciudad de la Habana, Cuba \\ ${ }^{2}$ Mycothèque de l'Université catholique de Louvain (MUCL), Member of the Belgian Coordinated \\ Collection of Microorganisms (BCCM), Croix du Sud 3, bte 6, 1348 Louvain-la-Neuve, Belgium \\ ${ }^{3}$ Department of Biology, University of Western Ontario, London, ON N6A 5B7, Canada
}

\begin{abstract}
A novel yeast species is described from 19 strains isolated from flowers and insects in three provinces of Cuba. The species is so far known only from Cuba. Characteristic asci and ascospores as well as phylogenetic analysis of the rDNA sequence place the novel species in the genus Metschnikowia. The novel species belongs to the New World subclade of large-spored species of Metschnikowia. Mating tests with other members of the subclade resulted in the formation of sterile asci without ascospores, showing that the Cuban strains represent a distinct biological species. Intraspecies matings lead to the production of fertile asci containing large needle-shaped ascospores. The novel species was further distinguished from its close relatives by rDNA sequences and PCR fingerprinting using primers derived from mini- and microsatellites. We propose the name Metschnikowia cubensis sp. nov. and designate MUCL $45753^{\top}(=\mathrm{CRGF}$ $279^{\top}=$ CBS $\left.10832^{\top}, \mathrm{h}^{+}\right)$as the type strain and MUCL $45751\left(=\right.$ CRGF $278=$ CBS $\left.10833, \mathrm{~h}^{-}\right)$ as the allotype.
\end{abstract}

Flowers have been known to harbour a significant yeast community since the studies of Boutroux (1884). Members of the genus Metschnikowia were among the first yeasts recovered from this habitat and were thought to be vectored by flower-associated insects (Reukauf, 19111912). They are among the best-studied yeasts with respect to their biogeography and ecology (Lachance et al., 2001, 2003). The genus Metschnikowia is characterized morphologically by elongated asci containing long needle-shaped ascospores. Within the genus, a subgroup of nutritionally homogeneous insect-associated Metschnikowia species is recognizable by the formation of generally large ascospores, $100-250 \mu \mathrm{m}$ length, in contrast to only $20-60 \mu \mathrm{m}$ in most other Metschnikowia species (Marinoni \& Lachance, 2004; Miller \& Phaff, 1998). The term 'large-spored Metschnikowia species' has been coined based on this character. Members of the group have so far been isolated only from the Americas and Hawai' $i$, and each species is limited in geographical distribution. Some species were shown to be endemic to the Hawaiian islands (Lachance et al., 2005), and their local distribution is assumed to be

The GenBank/EMBL/DDBJ accession number for the large-subunit rDNA sequence of strain MUCL $45753^{\top}$ is EU143316.

Further details on strain collection and results of mating tests are available as supplementary material with the online version of this paper. due to their close association with small nitidulid beetles and allopatric or peripatric speciation (Lachance et al., 2001; Marinoni \& Lachance, 2004). Some Candida species are members of the Metschnikowia clade as seen in phylogenetic analyses of rDNA sequences (Nguyen et al., 2006). Of these, Candida ipomoeae is an integral member of the New World large-spored subclade.

Cuba is recognized as a biodiversity hot spot, with approximately 6500 vascular plant species, of which more than $50 \%$ are endemic (Capote et al., 1989; http:// www.biodiversityhotspots.org/xp/Hotspots/caribbean/). The National Conservation Strategies for Fungi in Cuba reported the presence of only 10 species of the Saccharomycetales (Mena et al., 2003). This lack of knowledge of the yeasts of this region prompted us to investigate their diversity. The study has led to the finding of several undescribed species (Fidalgo-Jiménez et al., 2005). Nineteen strains were found to represent a novel species of the genus Metschnikowia, for which the name Metschnikowia cubensis sp. nov. is proposed.

\section{Isolation and preservation}

Nineteen strains of M. cubensis were found in about 500 samples from flowers of more than 120 plant species and some flower-associated insects taken in Cuba between 2001 and 2005. The samples yielded more than 400 yeast strains. 
Table 1. Origins of isolates considered in this study

Numbers following isolation sources signify individual flowers or insects that were sampled in the same location. The locations of the collection sites are given as: country, province, region/park/reserve, sampling location. ${ }^{\mathrm{T}}$, ex type; ${ }^{\mathrm{I}}$, ex isotype.

\begin{tabular}{|c|c|c|c|}
\hline Strain & Mating type & Isolation source & Location \\
\hline \multicolumn{4}{|l|}{ M. cubensis sp. nov. } \\
\hline MUCL 44438, CRGF 82 & $\mathrm{~h}^{-}$ & Flower of Talipariti elatum, Malvaceae & $\begin{array}{l}\text { Cuba, La Habana, Boyeros, Instituto de } \\
\text { Ecologia y Sistematica }\end{array}$ \\
\hline MUCL 44441, CRGF 83 & $\mathrm{~h}^{-}$ & Flower of T. elatum & As above \\
\hline $\begin{array}{l}\text { MUCL } 45753^{\mathrm{T}}, \text { CRGF } 279^{\mathrm{T}}, \text { CBS } \\
10832^{\mathrm{T}}\end{array}$ & $\mathrm{h}^{+}$ & Flower of T. elatum & $\begin{array}{l}\text { Cuba, Sanctí Spiritus, Alturas de Banao, } \\
\text { path El Regalo }\end{array}$ \\
\hline $\begin{array}{l}\text { MUCL 45751, CRGF 278, CBS } \\
10833\end{array}$ & $\mathrm{~h}^{-}$ & Flower of Gesneria humilis, Gesneriaceae & $\begin{array}{l}\text { Cuba, Sanctí Spiritus, Alturas de Banao, } \\
\text { house Maria Antonia }\end{array}$ \\
\hline MUCL 49175, CRGF 826 & $\mathrm{~h}^{+}$ & $\begin{array}{l}\text { Flower of Bidens alba var. radiata, } \\
\text { Asteraceae }\end{array}$ & $\begin{array}{l}\text { Cuba, Pinar del Río, Mil Cumbres, on the } \\
\text { way to the start of the pipe of the } \\
\text { hydroelectric plant }\end{array}$ \\
\hline MUCL 46753, CRGF 752 & $\mathrm{~h}^{+}$ & Flower of Tabebuia sp., Bignoniaceae & $\begin{array}{l}\text { Cuba, Pinar del Río, Mil Cumbres, } \\
\text { Reserva San Marcos }\end{array}$ \\
\hline MUCL 51011, CRGF 833 & $\mathrm{~h}^{-}$ & $\begin{array}{l}\text { Individual } 1 \text { of Conotelus sp. in flower } 1 \\
\text { of Ipomoea acuminata, Convolvulaceae }\end{array}$ & $\begin{array}{l}\text { Cuba, Sanctí Spiritus, Topes de Collantes, } \\
\text { start of path to the Salto de Cabuni }\end{array}$ \\
\hline MUCL 51012, CRGF 842 & $\mathrm{~h}^{+}$ & $\begin{array}{l}\text { Individual } 1 \text { of Conotelus sp. in flower } 1 \\
\text { of I. acuminata }\end{array}$ & As above \\
\hline MUCL 51013, CRGF 834 & $\mathrm{~h}^{+}$ & $\begin{array}{l}\text { Individual } 3 \text { of Conotelus sp. in flower } 1 \\
\text { of I. acuminata }\end{array}$ & As above \\
\hline MUCL 51014, CRGF 835 & $\mathrm{~h}^{+}$ & Flower 1 of I. acuminata & As above \\
\hline MUCL 51015, CRGF 836 & $\mathrm{~h}^{-}$ & Ant in flower of T. elatum & $\begin{array}{l}\text { Cuba, Sanctí Spiritus, Topes de Collantes, } \\
\text { south of Hotel Escambray }\end{array}$ \\
\hline MUCL 49859, CRGF 828 & $\mathrm{~h}^{+}$ & Pollen of T. elatum & As above \\
\hline MUCL 51016, CRGF 837 & $\mathrm{~h}^{-}$ & Pollen of T. elatum & As above \\
\hline MUCL 49860, CRGF 829 & $\mathrm{~h}^{+}$ & Flower 1 of I. acuminata & $\begin{array}{l}\text { Cuba, Sanctí Spiritus, Topes de Collantes, } \\
\sim 500 \mathrm{~m} \text { from Hotel Escambray }\end{array}$ \\
\hline MUCL 51017, CRGF 838 & $\mathrm{~h}^{-}$ & Flower 2 of I. acuminata & As above \\
\hline MUCL 51018, CRGF 839 & $\mathrm{~h}^{-}$ & Flower 1 of I. acuminata & $\begin{array}{l}\text { Cuba, Sanctí Spiritus, Topes de Collantes, } \\
\sim 1500 \mathrm{~m} \text { from Hotel Escambray }\end{array}$ \\
\hline MUCL 49858, CRGF 827 & $\mathrm{~h}^{-}$ & Flower of T. elatum & $\begin{array}{l}\text { Cuba, Pinar del Río, Mil Cumbres, near } \\
\text { cabin Los Pinos }\end{array}$ \\
\hline MUCL 51019, CRGF 840 & $\mathrm{~h}^{+}$ & Fallen flower of T. elatum & $\begin{array}{l}\text { Cuba, Pinar del Río, Viñales valley, camp } \\
\text { Cueva Los Portales }\end{array}$ \\
\hline MUCL 51020, CRGF 841 & $\mathrm{~h}^{-}$ & Flower 5 of blue Ipomoea sp. & $\begin{array}{l}\text { Cuba, Pinar del Río, Viñales valley, } \\
\text { roadside between Viñales and Pons, near } \\
\text { path 'Maravillas de Viñales' }\end{array}$ \\
\hline \multicolumn{4}{|l|}{ Metschnikowia sp. } \\
\hline $\begin{array}{l}\text { MUCL 46232, UWOPS 00-154.1 } \\
\text { M. lochheadii }\end{array}$ & $\mathrm{h}^{-}$ & Conotelus sp. collected on Merremia tuberosa & Costa Rica, Guanacaste, Dos Ríos \\
\hline $\begin{array}{l}\text { MUCL } 46297^{\mathrm{T}} \text {, UWOPS } \\
00-133.2^{\mathrm{T}}\end{array}$ & $\mathrm{h}^{+}$ & $\begin{array}{l}\text { Conotelus mexicanus collected on Tabebuia } \\
\text { rosea }\end{array}$ & Costa Rica, Guanacaste \\
\hline $\begin{array}{l}\text { MUCL } 46298^{\mathrm{I}} \text {, UWOPS } 99-661.1^{\mathrm{I}} \\
\text { C. ipomoeae }\end{array}$ & $\mathrm{h}^{-}$ & C. mexicanus collected on Brugsmansia candida & USA, Hawaii, Maui Island \\
\hline $\begin{array}{l}\text { MUCL } 46294^{\mathrm{T}}, \text { UWOPS } 91- \\
672.1^{\mathrm{T}}\end{array}$ & Unknown & $\begin{array}{l}\text { Exalloscaptomyza calliginosa collected on } \\
\text { I. acuminata }\end{array}$ & USA, Hawaii, Hawaii Island \\
\hline
\end{tabular}

The distances between the three larger collection areas are between 130 and $440 \mathrm{~km}$. The strains and their isolation substrates are listed in Table 1. More detailed information about the collections is provided in Supplementary Table $\mathrm{S} 1$, available in IJSEM Online.

For yeast isolation, flowers were placed in sterile plastic bags or sterile tubes depending on their size. For large flowers (e.g. Malvaceae), $150 \mu \mathrm{l}$ sterile water was added into each flower to release yeast cells adhering to their surface. Small flowers (e.g. Asteraceae) were taken with sterile forceps and immersed in $1000 \mu$ sterile water. In both cases, $100 \mu$ l of the wash fluid was diluted 10 -fold and $100 \mu \mathrm{l}$ of this dilution was spread on DYPA (2\% glucose, $1 \%$ peptone, $0.5 \%$ yeast extract, $2 \%$ agar) supplemented 
with $0.02 \%$ chloramphenicol. Insects were placed on Petri dishes with the same medium, allowed to move around for $2-5$ min and then removed. The cultures were incubated at ambient temperature and examined every $12 \mathrm{~h}$ for $72 \mathrm{~h}$. Representative colonies of each morphological type were purified and maintained on DYPA. All strains have been deposited in the Collection of Fungal Genetic Resources (CRGF), Cuba, with duplicates at the MUCL. They are preserved on agar slants under oil and under water at CRGF and cryopreserved at $-130{ }^{\circ} \mathrm{C}$, lyophilized, on agar slants under oil and under water at MUCL. The type strains were also deposited at the Centraalbureau voor Schimmelcultures (CBS).

\section{Growth characteristics}

The strains were characterized by 96 morphological and physiological tests, performed with the microplate-based ALLEV system (Robert et al., 1997), following the methods of Kreger-van Rij (1987) and Van der Walt \& Yarrow (1984). The strains showed some slightly variable growth reactions, which are represented in the species description. Measurements of cells and ascospores were obtained based on micrographs with the BioloMICS software (BioAware) and are given in the description.

The mating type for MUCL $45753^{\mathrm{T}} \mathrm{h}^{+}$and MUCL 45751 $\mathrm{h}^{-}$was determined by mixing active cultures of the two strains on yeast carbon base (Difco) supplemented with $0.01 \%$ ammonium sulphate and $1.5 \%$ agar, followed by periodic examination by phase-contrast microscopy. Quantitative assessment of ascospore formation for selected strains was performed as follows. Cells of active cultures were suspended in sterile water and the cell density was adjusted visually to McFarland standard $2\left(\sim 20 \times 10^{6}\right.$ cells $\mathrm{ml}^{-1}$ ). Five hundred microlitre aliquots of each mating partner were mixed and four $50 \mu$ laliquots of the mixtures were spot-inoculated onto GYA ( $1 \%$ glucose, $0.01 \%$ yeast extract, $2 \%$ agar) and the plates were incubated at $18{ }^{\circ} \mathrm{C}$. Slides were prepared using cotton blue ( $5 \mathrm{mg}$ cotton blue $\mathrm{ml}^{-1}$ in lactic acid) and examined every $12 \mathrm{~h}$. For each slide, 50 asci were scored for the presence of ascospores and the results after $72 \mathrm{~h}$ incubation are reported in Supplementary Table S2. Mating types were assigned based on the formation of sterile asci in crosses with authentic strains of other species and are thus consistent with those of all other large-spored Metschnikowia species. Species delineation was based on the development of fertile asci with two ascospores in compatible mating reactions. A minimum percentage of $70 \%$ fertile asci was found for the strain combination MUCL $46753^{\mathrm{T}} \mathrm{h}^{+} \times$MUCL $45751 \mathrm{~h}^{-}$. All other intraspecies combinations showed more than $80 \%$ fertile asci (Supplementary Table S2). The combination of $M$. cubensis strains with compatible mating types of Metschnikowia lochheadii (MUCL $46297 \mathrm{~h}^{+}$, MUCL $46298 \mathrm{~h}^{-}$) and Metschnikowia sp. UWOPS 00-154.1 produced sterile asci.

\section{DNA-based studies}

Extraction of high-molecular-mass DNA was performed by a combination of the Qiagen DNeasy procedure and the Invisorb Spin Plant Mini kit (Invitek) with modifications. From a culture grown on DYPA for $72 \mathrm{~h}$ at $25{ }^{\circ} \mathrm{C}$, three $10 \mu \mathrm{l}$ loops of cells were resuspended in $600 \mu \mathrm{l}$ sorbitol buffer (1 M sorbitol, $100 \mathrm{mM}$ sodium EDTA, $14 \mathrm{mM} \beta$ mercaptoethanol) and $200 \mathrm{U}$ lyticase (L4025; Sigma). The samples were shaken overnight at $30{ }^{\circ} \mathrm{C}$, the suspension was centrifuged for $2 \mathrm{~min}$ at 12000 r.p.m., the supernatant was discarded, $400 \mu \mathrm{l}$ lysis buffer $\mathrm{P}$ and $20 \mu \mathrm{l}$ proteinase $\mathrm{K}$ were added and finally the mixture was homogenized with a pipette tip and incubated for $30 \mathrm{~min}$ at $65{ }^{\circ} \mathrm{C}$. The solution was then transferred onto a spin filter and centrifuged for $5 \mathrm{~min}$ at 12000 r.p.m. and $6 \mu \mathrm{l}$ RNase (100 $\mathrm{mg} \mathrm{ml}^{-1}$ in molecular biology grade water) was then added to the filtrate, which was vortexed briefly and incubated for $5 \mathrm{~min}$ at room temperature. Binding buffer $\mathrm{P}$ $(200 \mu \mathrm{l})$ was added and the sample was vortexed briefly and then transferred to a fresh spin filter and centrifuged for $1 \mathrm{~min}$ at 12000 r.p.m. Wash buffer I $(550 \mu \mathrm{l})$ was then added to the spin filter, which was centrifuged as before; the filtrate was discarded, followed by a similar treatment using wash buffer II and a final treatment with $400 \mu \mathrm{l}$ wash buffer II and centrifugation for $2 \mathrm{~min}$ at 12000 r.p.m. The DNA was eluted with $100 \mu 165{ }^{\circ} \mathrm{C}$ molecular biology grade water for $3 \mathrm{~min}$ and centrifuged for $1 \mathrm{~min}$ at 10000 r.p.m. This DNA solution, stored at $4{ }^{\circ} \mathrm{C}$ for short-term preservation and at $-20{ }^{\circ} \mathrm{C}$ for long-term preservation, was used for PCR fingerprinting and DNA sequence determinations.

PCR fingerprinting was performed using the minisatellitespecific oligonucleotide derived from the core sequence of the bacteriophage M13 (Vassart et al., 1987) with the sequence $5^{\prime}$-GAGGGTGGCGGTTCT-3' and the microsatellite-specific oligonucleotides (GACA $)_{4},(\mathrm{GTG})_{5}$ and $(\mathrm{ATG})_{5}$ as single PCR primers. PCR amplifications were performed in $25 \mu \mathrm{l}$ reaction volumes containing $10 \mathrm{ng}$ genomic DNA, $0.13 \mu \mathrm{M}$ primer, $0.2 \mathrm{mM}$ dNTPs, $4.5 \mathrm{mM}$ $\mathrm{MgCl}_{2}$ and $2.5 \mathrm{U}$ AmpliTaq DNA polymerase (Applied Biosystems). Amplifications were carried out in an Eppendorf Mastercycler programmed for 35 cycles $(20 \mathrm{~s}$ at $94{ }^{\circ} \mathrm{C}, 60 \mathrm{~s}$ at $50{ }^{\circ} \mathrm{C}, 20 \mathrm{~s}$ at $72{ }^{\circ} \mathrm{C}$ ), followed by $6 \mathrm{~min}$ final extension at $72{ }^{\circ} \mathrm{C}$ and cooling to $4{ }^{\circ} \mathrm{C}$. Amplified DNA fragments were separated by electrophoresis in $1.4 \%$ agarose dissolved in TBE buffer, stained with $0.6 \times$ GelRed (approx. $0.8 \mu \mathrm{g} \mathrm{ml}^{-1}$; Biotium) and photographed under UV light (Fig. 1). The species selection for PCR fingerprint analysis was based on the smallest differences in the D1/D2 large-subunit (LSU) rDNA sequence among type strains of M. cubensis vs Candida ipomoeae with five substitutions and two indels, vs Metschnikowia sp. UWOPS 00-154.1 with three substitutions and four indels and vs $M$. lochheadii with seven substitutions and one indel. The DNA banding patterns with the primers M13, (GTG) $)_{5}$ and (ATG) $)_{5}$ were generally similar within $M$. cubensis and $M$. lochheadii, and dissimilar between the four species 


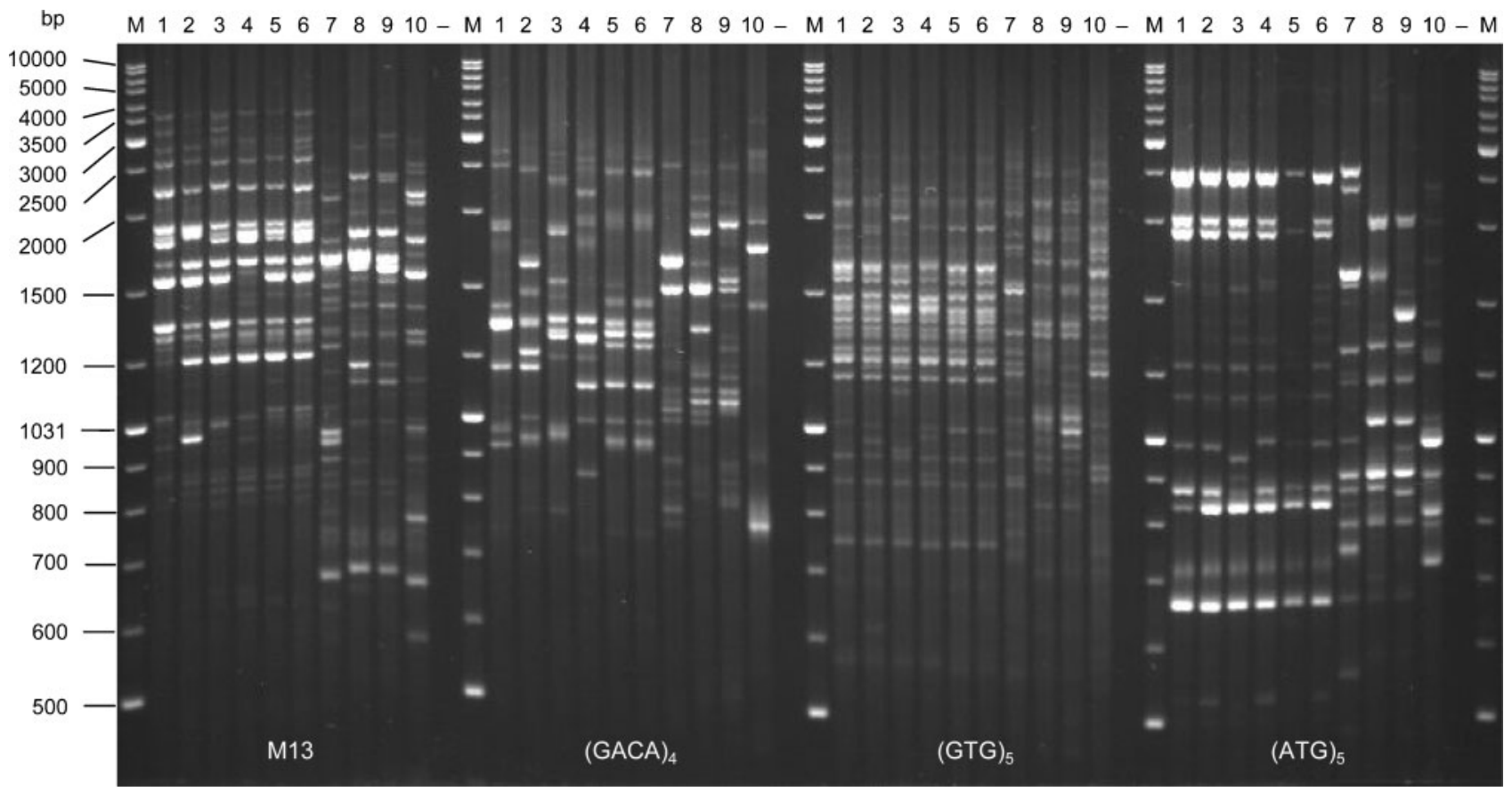

Fig. 1. $P C R$ fingerprinting profiles with primers $M 13,(\mathrm{GACA})_{4},(\mathrm{GTG})_{5}$ and $(\mathrm{ATG})_{5}$ for selected strains of Metschnikowia cubensis sp. nov. and type strains of the most closely related species. Lanes: M, markers; 1, MUCL 49175; 2, MUCL 46753; 3 , MUCL 45753'; 4, MUCL 45751; 5, MUCL 44441; 6, MUCL 44438; 7, Metschnikowia sp. UWOPS 00-154.1; 8, M. loch headii UWOPS 00-133.2 ${ }^{\top} ; 9$, M. lochheadii UWOPS 99-661.1'; 10, Candida ipomoeae UWOPS 91-672.1 ${ }^{\top} ;-$, negative control. ' , ex type; ', ex isotype.

compared. The DNA amplified with the primer (GACA) 4 shows a large degree of intraspecies variation in M. cubensis and almost identical patterns for MUCL 44441 and MUCL 44438 that were isolated in close proximity to each other, suggesting that (GACA) ${ }_{4}$ might be most useful for differentiation at the population level.

\section{Phylogenetic relationships}

Comparison of D1/D2 sequences of the type and allotype strains originally indicated that $M$. cubensis may be closely related to M. lochheadii, Metschnikowia sp. strain UWOPS 00-154.1, and C. ipomoeae. However, the phylogenetic signals of the D1/D2, internal transcribed spacer (ITS) and intergenic spacer (IGS) components of the nuclear rDNA have been shown not to be perfectly congruent in the largespored group (Marinoni \& Lachance, 2004). Separate phylogenetic analyses of various partitions of the rDNA repeat showed that the LSU, including the D1/D2 region, favoured a sisterhood of M. cubensis with C. ipomoeae and that the D1/D2 LSU alone lead to the placement of these two taxa next to M. lochheadii and UWOPS 00-154.1. Small-subunit (SSU) rDNA trees indicated a sister relationship of $M$. cubensis and Metschnikowia borealis, with $70 \%$ bootstrap support. No other bootstrap-supported groups could be detected in these analyses, indicating a low information content of SSU sequences for this comparison. As none of the rDNA partitions resolved the relationships, the tree presented in Fig. 2 is based on the complete transcribed region of the rDNA. The IGS sequences could not be aligned in a satisfactory manner and were deleted from the analysis. The sequences

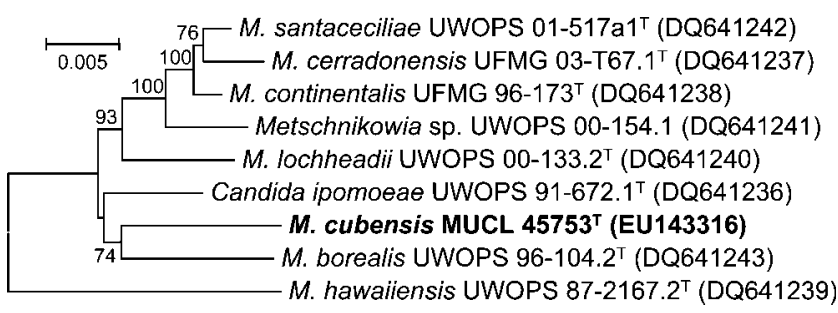

Fig. 2. Neighbour-joining phylogram of selected large-spored Metschnikowia species showing the placement of M. cubensis based on 5638 aligned nucleotide positions of rDNA sequences including the external transcribed spacer, SSU gene, internal transcribed spacers 1 and 2, 5.8S gene and the LSU gene. Shown is the tree obtained in MEGA 3.1 under Kimura's two-parameter model with gapped alignment positions deleted during the pairwise sequence comparisons. The analysis was replicated 1000 times and only bootstrap values greater than $70 \%$ are shown. The root was positioned on the midpoint of the longest path between two taxa. Bar, $0.5 \%$ sequence divergence. 
were obtained as described in Rosa et al. (2007). Analyses by maximum-parsimony (results not shown) and neighbour-joining (Fig. 2) suggest that M. cubensis occupies a fairly basal position within the New World large-spored species. A possible sisterhood with $M$. borealis, an eastern North American endemic, is not supported by bootstrap analysis in the parsimony analysis and received intermediate bootstrap values in the neighbour-joining analysis. The neighbour-joining bootstrap values should be interpreted with caution, as varying rates of nucleotide substitution might lead to incorrect branching patterns receiving high bootstrap values.

\section{Geographical distribution and ecology}

The low frequency with which the species was found indicated that its true specific habitat has not yet been identified unequivocally. Strains were obtained either from flowers found in clearings of tropical wet forest, at forest edges, in abandoned gardens or from insects found in flowers (Table 1). These habitats were characterized by a general abundance of ascomycetous yeasts. The relatively large distances between the three larger collection areas, Sierra del Escambray, Cordillera de Guaniguanico and La Habana, and the frequent occurrence of similar disturbed habitats suggest that the species is widely distributed throughout central and western Cuba. On the Peninsula de Guanahacabibes in the far west of Cuba and in the Cuchillas del Toa near the north-eastern coast, where similar numbers of samples were collected and analysed by similar methods, no isolates of $M$. cubensis have yet been found. Both mating types were present in all collection areas with the exception of La Habana, from where only two isolates are known. From two samples, from Conotelus sp. and pollen, respectively, two isolates each with opposite mating types were obtained. This and the balanced occurrence of the two mating types among the isolates suggests that the species forms one sexually reproducing population. M. cubensis was isolated from flowers of five plant species and associated insects with a repeated occurrence on Talipariti elatum, a tree with hibiscus-like flowers formerly classified as Hibiscus elatus, and on Ipomoea acuminata. The isolation plates of one Conotelus sp. individual, the Ipomoea acuminata flower containing Conotelus sp. and a fallen Talipariti elatum flower were noted for particularly large numbers of 100-200 yeast colonies of homogeneous morphology (Supplementary Table S1). A specific association of New World largespored Metschnikowia species with floricolous beetles (Conotelus spp., Nitidulidae) has been reported (Lachance et al., 2001, 2003). Beetles of this genus have been found in all sampled localities in North, Central and South America and have been shown to harbour large populations of large-spored Metschnikowia species. Although the current study focused on yeasts of flowers and Cuban Conotelus sp. were not sampled repeatedly, it is likely that they are involved in the transmission of $M$. cubensis.

\section{Species identification}

The genus Metschnikowia is morphologically and physiologically homogeneous (Miller \& Phaff, 1998). Identification of M. cubensis is therefore not possible based on these features owing to the similarity with related species. The novel species is included in the genus Metschnikowia based on the large cylindrical asci with one or two needle-shaped ascospores and phylogenetic analysis of rDNA sequences (Fig. 2). M. cubensis can be separated from related Metschnikowia species by reproductive isolation in compatible mating reactions, PCRfingerprinting profiles produced with the primers M13, $(\mathrm{GTG})_{5}$ and $(\mathrm{ATG})_{5}$, and by sequencing of D1/D2 LSU or other rDNA components.

\section{Latin diagnosis of Metschnikowia cubensis Fidalgo-Jiménez, Daniel, Evrard, Decock et Lachance sp. nov.}

Post dies tres in medio DYPA cultura parva, convexa, aliquando cum margina filamentosa, candida aut cremea, lucida et rugosa, aliquando cerebriformis. Cellulae globosae ad ellipsoidae $(2-4 \times 2-5 \mu \mathrm{m})$. Cultura in agaro PDA post dies 7 pseudomycelium formatur. Mycelium verum formatum tuborum longorum. Post dies unus, cellulae stirpum interfertilium mixtarum in agaro carbonis fundamento tubi junctionis formantur. Post dies tres, magni asci cylindrati $(80-120 \mu \mathrm{m})$ possunt videri. Asci stabiles sunt. Ascosporae aculeatae. Glucosum, galactosum et trehalosum (omnia variabile) fermentantur. Glucosum, galactosum, L-sorbosum, D-xylosum, sucrosum (aliquando exigue), maltosum, trehalosum, cellobiosum, salicinum, arbutinum (aliquando exigue), melezitosum, glycerolum (aliquando exigue), xylitolum (aliquando exigue), glucitolum, mannitolum, gluconolactonum (variabile), 2-ketogluconatumm, D-gluconatum (aliquando exigue), acidum succinicum (aliquando exigue), ethanolum (aliquando exigue), propanum-1,2-diolum (aliquando exigue), assimilantur at non D-glucosaminum, Dribosum (variabile), L-arabinosum, D-arabinosum, L-rhamnosum, methyl- $\alpha$-D-glucosidum, melibiosum, lactosum, raffinosum, inulinum, erythritolum, ribitolum (aliquando exigue), L-arabinitolum, galactitolum, myo-inositolum, 5ketogluconatum (aliquando exigue), D-glucuronatum, acidum lacticum (aliquando exigue), acidum citricum (aliquando exigue), methanolum nec butanum-2,3-diolum (aliquando exigue). Ethylaminum, lysinum et cadaverinum assimilantur at non natrium nitricum nec natrium nitrosum, creatinum (variabile), creatininum, glucosaminum aut imidazolum. Ad crescentiam biotinum et thiaminum externa necessaria sunt. Augmentum in $30^{\circ} \mathrm{C}$, at non $37^{\circ} \mathrm{C}$.

Typus MUCL $45753^{\mathrm{T}}$ e flore Talipariti elatum et allotypus MUCL 45751 e flore Gesneria humilis, Cuba. In collectione zymotica Centraalbureau voor Schimmelcultures, Trajectum ad Rhenum, sub no. CBS $10832^{\mathrm{T}}$ et CBS 10833 depositae sunt. 

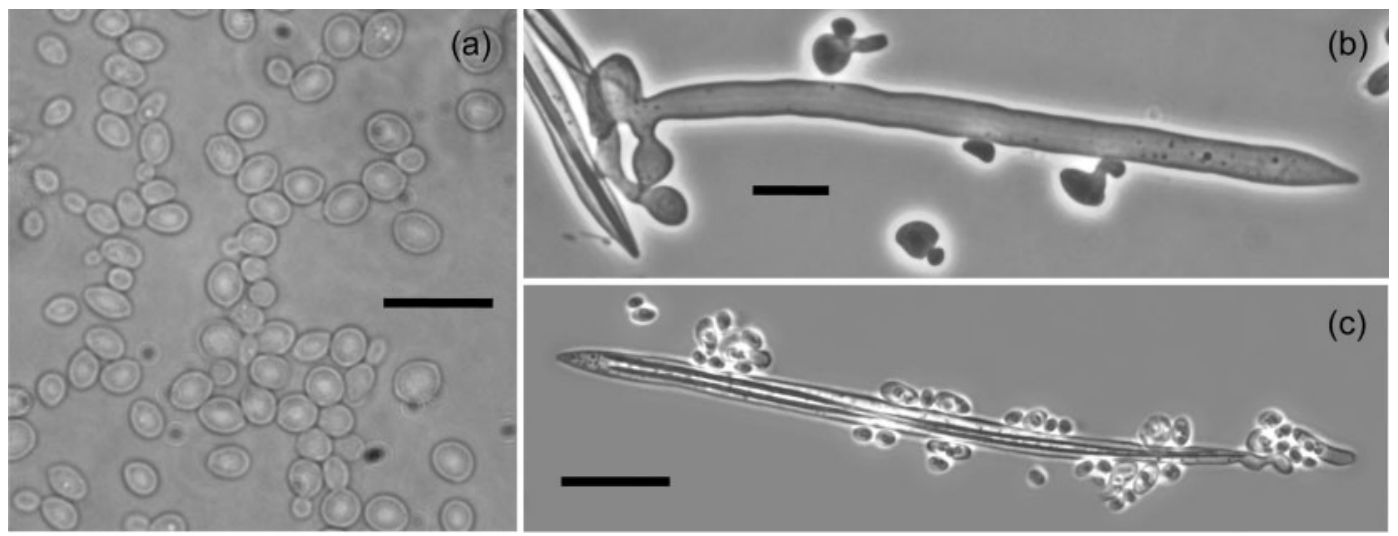

Fig. 3. Phase-contrast micrographs of $M$. cubensis MUCL $45753^{\top}$. (a) Vegetative cells on DYPA at $25{ }^{\circ} \mathrm{C}$ after $72 \mathrm{~h}$. (b, c) Strain MUCL $45753^{\top}$ in mixture with allotype MUCL 45751 on GYA at $18^{\circ} \mathrm{C}$ after $72 \mathrm{~h}$ showing a sterile ascus (b) and an ascus with two ascospores (c). Bars, $10 \mu \mathrm{m}$.

\section{Description of Metschnikowia cubensis Fidalgo-Jiménez, Daniel, Evrard, Decock et Lachance sp. nov.}

Metschnikowia cubensis (cu.ben'sis. N.L. nom. fem. sing. adj. cubensis of Cuba, referring to the country where all currently known strains were recovered).

Mycobank number: MB 511354.

After $72 \mathrm{~h}$ on DYPA at $25{ }^{\circ} \mathrm{C}$, colonies are small, circular, convex, occasionally with a mycelial margin, white to cream, glistening and rugose. Some colonies are cerebriform. No pigment is observed. Cells are ovoidal to ellipsoidal, occur singly or in pairs and measure $2-4 \times 2-$ $5 \mu \mathrm{m}$ (Fig. 3). Vegetative reproduction by multilateral budding is observed. In Dalmau plate cultures on PDA (potato dextrose agar $3.9 \%$, agar $0.2 \%$ ) after 7 days at $25{ }^{\circ} \mathrm{C}$, pseudomycelium is formed and, more rarely, also true hyphae with rare septa are present. After $12 \mathrm{~h}$ on GYA at $18{ }^{\circ} \mathrm{C}$, mixed cultures of complementary mating types show conjugated cells, zygotes and immature asci. After 3 days, mature and immature asci are present. Asci are large and cylindrical, usually retaining the original zygote. Mature asci contain two needle-shaped ascospores measuring $80-120 \mu \mathrm{m}$ in length (Fig. 3). Evanescence of asci is not observed after 30 days of incubation. Glucose, galactose and trehalose fermentation is variable. Reactions are listed as observed in the type strain; reactions of additional strains are indicated in parentheses. Glucose, galactose, L-sorbose, xylose, sucrose (sometimes weak), maltose, trehalose, cellobiose, salicin, arbutin (sometimes weak), melezitose, glycerol (sometimes weak), xylitol (sometimes weak), glucitol, mannitol, D-glucono-1,5lactone (variable), 2-keto-D-gluconate, D-gluconate (sometimes weak), succinate (sometimes weak), ethanol (variable and weak) and propane-1,2-diol (variable and weak) are assimilated, but not D-glucosamine, D-ribose (variable), Larabinose, D-arabinose, L-rhamnose, methyl $\alpha$-D-glucoside, melibiose, lactose, raffinose, inulin, erythritol, ribitol (sometimes weak), L-arabinitol, galactitol, myo-inositol, 5-ketogluconate (sometimes weak), D-glucuronate, Dgalacturonate, DL-lactate (sometimes weak), citrate (sometimes weak), methanol or butane-2,3-diol (sometimes weak). Ethylamine, L-lysine and cadaverine are utilized as nitrogen sources, but not nitrate, nitrite, creatine (variable), creatinine, glucosamine or imidazole. Biotin and thiamine are required for growth. Arbutin hydrolysis is variable. Growth is not observed in the presence of $0.1 \%$ cycloheximide or $1 \%$ acetic acid. Grows in the presence of $50 \%$ glucose. Starch formation, acetic acid production and urea hydrolysis are not observed. The Diazonium blue B reaction is negative. Grows at $30{ }^{\circ} \mathrm{C}$ but not at $37{ }^{\circ} \mathrm{C}$.

The type strain is strain MUCL $45753^{\mathrm{T}}\left(\mathrm{h}^{+}\right)\left(=\mathrm{CRGF} 279^{\mathrm{T}}\right.$ $=$ CBS $10832^{\mathrm{T}}$ ), isolated as I-206 by one of the authors (A. F.-J.) from a flower of Talipariti elatum on 27 January 2004 at vereda El Regalo, Alturas de Banao, Province Santí Spiritus, Cuba. The allotype strain is strain MUCL 45751 $\left(\mathrm{h}^{-}\right)(=\mathrm{CRGF} 278=\mathrm{CBS} 10833)$, isolated as I-254 by one of the authors (A. F.-J.) from a flower of Gesneria humilis on 29 January 2004 at casa Maria Antonia, Alturas de Banao, Province Santí Spiritus, Cuba.

\section{Acknowledgements}

This research was supported by the Conseil Inter-Universitaire de la Communauté Française de Belgique: Commission Universitaire pour le Développement (CIUF-CUD-MUCL-Cuba), the Belgian Federal Science Policy (BCCM C2/10/007 and BCCM C3/10/003) and the European Commissions Marie Curie Mobility Actions (MIRG-CT2005-016539). A. F.-J. thanks the Cuban Ministry of Science, Technology and Environment for providing facilities and financial support. M.-A. L. acknowledges funding from the Natural Science and Engineering Research Council of Canada. We greatly appreciate the assistance of R. Oviedo, I. Ventosa and I. Fuentes with plant identification, R. Carbonell Paneque for supporting work at the field station of Mil Cumbres, S. de Pedro Alderete for some of the yeast collections, S. Huret and C. Bivort with the generation of the DNA sequences and M. C. Moons with physiological characterization. 


\section{References}

Boutroux, M. L. (1884). Conservation des ferments alcooliques dans la nature. Ann Sci Nat Bot 17, 145-209 (in French).

Capote, R. P., Berazaín, R. \& Leiva, A. (1989). Cuba. In Floristic Inventory of Tropical Countries: The Status of Plant Systematics, Collections, and Vegetation, Plus Recommendations for the Future, pp. 315-335. Edited by D. G. Campbell \& D. Hammond. New York: New York Botanical Garden.

Fidalgo-Jiménez, A., Evrard, P., Decock, C. \& Daniel, H. M. (2005). Ecological Survey of Yeasts in Cuba. Brasília: Latin-American Congress of Mycology.

Kreger-van Rij, N. J. W. (1987). Classification of yeasts. In The Yeasts, 2nd edn, vol. 1, pp. 5-61. Edited by A. H. Rose \& J. S. Harrison. London: Academic Press.

Lachance, M. A., Starmer, W. T., Rosa, C. A., Bowles, J. M., Baker, J. S. F. \& Janzen, D. H. (2001). Biogeography of the yeasts of ephemeral flowers and their insects. FEMS Yeast Res 1, 1-8.

Lachance, M. A., Bowles, J. M. \& Starmer, W. T. (2003). Geography and niche occupancy as determinants of the yeast biodiversity: the yeast-insect-morning glory ecosystem of Kipuka Puaulu, Hawai'i. FEMS Yeast Res 4, 105-111.

Lachance, M.-A., Ewing, C. P., Bowles, J. M. \& Starmer, W. T. (2005). Metschnikowia hamakuensis sp. nov., Metschnikowia kamakouana sp. nov. and Metschnikowia mauinuiana sp. nov., three endemic yeasts from Hawaiian nitidulid beetles. Int J Syst Evol Microbiol 55, 1369-1377.

Marinoni, G. \& Lachance, M. A. (2004). Speciation in the large-spored Metschnikowia clade and establishment of a new species, Metschnikowia borealis comb. nov. FEMS Yeast Res 4, 587-596.
Mena, P. J., Herrera, F. S., Mercado, S. A., Minter, D., Iglesias, B. H., Blanco, H. N., Ortiz, M. J. L., Maldonado, G. S., Recio, H. G. \& other authors (2003). Estrategia para la conservación de la diversidad fúngica en Cuba. In Mem. IV Convención Internacional de Medioambiente y Desarrollo, pp. 262-282. Havana: Palacio de las Convenciones (in Spanish).

Miller, M. W. \& Phaff, H. J. (1998). Metschnikowia Kamienski. In The Yeasts, a Taxonomic Study, 4th edn, pp. 256-270. Edited by C. P. Kurtzman \& J. W. Fell. Amsterdam: Elsevier Science.

Nguyen, N. H., Suh, S. O., Erbil, C. K. \& Blackwell, M. (2006). Metschnikowia noctiluminum sp. nov., Metschnikowia corniflorae sp. nov., and Candida chrysomelidarum sp. nov., isolated from green lacewings and beetles. Mycol Res 110, 346-356.

Reukauf, E. (1911-1912). Nektarhefen. Die Kleinwelt 3, 25-26 (in German).

Robert, V., Evrard, P. \& Hennebert, G. L. (1997). BCCM/ALLEV 2.00 an automated system for the identification of yeasts. Mycotaxon 64, 455-463.

Rosa, C. A., Lachance, M.-A., Teixeira, L. C. R. S., Pimenta, R. S. \& Morais, P. B. (2007). Metschnikowia cerradonensis sp. nov., a yeast species isolated from ephemeral flowers and their nitidulid beetles in Brazil. Int J Syst Evol Microbiol 57, 161-165.

Van der Walt, J. P. \& Yarrow, D. (1984). Methods for the isolation, maintenance, classification and identification of yeasts. In The Yeasts, a Taxonomic Study, pp. 45-104. Edited by N. J. W. Kreger-van Rij. London: Elsevier.

Vassart, G., Georges, M., Monsieur, R., Brocas, H., Lequarre, A. S. \& Cristophe, D. (1987). A sequence in M13 phage detects hypervariable minisatellites in human and animal DNA. Science 235, 683-684. 